\title{
What Beliefs are Associated with COVID Vaccination Intentions? Implications for Campaign Planning
}

\author{
Robert Hornik, Chioma Woko, Leeann Siegel, Kwanho Kim, Ava Kikut, Emma Jesch, Danielle \\ Clark $^{1}$
}

Annenberg School for Communication, University of Pennsylvania

$11 / 27 / 2020$ This is a preprint version, not yet subject to peer review.

\begin{abstract}
COVID vaccination intentions vary among the US population. We report the results of a nationally representative survey undertaken in July $2020(\mathrm{~N}=889)$ that examined the association of six vaccine-specific beliefs with intentions to vaccinate. We find that four of the six beliefs have substantial associations with intention (Gammas between .60 and .77), that the associations mostly do not vary with gender, age, race/ethnicity, or misinformation (even though intentions do vary with each of those variables). Also, once adjusted for the vaccinespecific beliefs, level of misinformation is not related to intentions. We consider the implications of these results and argue both that persuasive campaigns can be informed by these specific results, and given rapid changes in vaccine availability, that there is a substantial need for elaborated and repeated follow-up studies.
\end{abstract}

\footnotetext{
${ }^{1} \mathrm{RH}$ led the study, all other authors are listed in reverse alphabetical order
} 
What Beliefs are Associated with COVID Vaccination Intentions?

Implications for Campaign Planning

At this moment, there is great optimism about the potential for vaccination to limit the spread and illness consequences of the novel coronavirus pandemic. That optimism relies on the assumption that the population will readily accept vaccination, an assumption that is, however, uncertain. The available evidence about individual intentions to accept the vaccine suggests that a substantial percentage of the population is wary. Depending on the survey, between 2533 percent have expressed reluctance (cf. Head et al., 2020; Thigpen and Funk, 2020; Consumer Reports, 2020). There is evidence, also, from these same sources that wariness varies among segments of the population. Of course, as the public discussion absorbs the quickly evolving evidence about vaccine effectiveness and safety, it may be that public opinion will evolve as well, and wariness will give way to willingness. Nonetheless, we know that other vaccines have not been universally accepted, despite high efficacy and safety profiles. It is urgent that careful consideration be given to 'what if' - what shape should persuasive communication take if the population as a whole, or substantial subsegments, drag their feet?

We argue here that planning for persuasive communication campaigns ought to focus on addressing beliefs that have been shown to be substantially related to intentions to vaccinate. Their goal should be persuading people to change those beliefs. At the same time, beliefs that have smaller associations with intentions will not merit attention in campaigns (cf. Brennan et al., 2017; Hornik and Woolf, 1999; Lee et al., 2016).

Relying on a recent survey, described below, we examine the cross-sectional associations of intention to vaccinate with six beliefs about the consequences of COVID vaccination for respondents; we also present parallel associations with vaccination intentions for a scale made up of eight beliefs that are categorized as misinformation related to COVID-19. We show that some of the vaccination-related beliefs are more sharply related to vaccine intentions than others, and that the vaccination-specific beliefs are more relevant to vaccination intentions than the misinformation beliefs. We also show that such misinformation beliefs do not account for vaccination intentions once vaccination beliefs are statistically controlled (see also: Woko et al., 2020).

\section{The Study}

A nationally representative sample of adults $(n=1,074)$ was recruited from Social Science Research Solutions (SSRS)'s Opinion Panel (Social Science Research Solutions (SSRS), n.d.). Participants completed surveys either online or by phone (landline or cell phone) and in either English or Spanish. Participants were first interviewed between 05/26/2020 and 06/12/2020 (T1) and then again around six weeks later between 07/15/2020 and 07/21/2020 (T2). The survey cooperation rate was $54 \%$ at $\mathrm{T} 1$, and $83 \%$ of respondents were successfully reinterviewed at T2 $(n=889)$. SSRS developed survey weights to ensure the sample matched the U.S. population on key demographic characteristics. All of the analyses reported below make use of the T2 data; the vaccine-related belief measures were only gathered then. The study was approved by University of Pennsylvania's Institutional Review Board (IRB). 


\section{Measures}

The follow-up survey measured six specific beliefs about vaccination. Each measure asked specifically about a different consequence for the respondent associated with getting the coronavirus vaccination: The stem for all items was: "How much do you (disagree) or (agree) that if you were to receive a potential coronavirus...?" completed with the following six phrases: a) you would suffer bad side effects from the vaccine, b) it would be a financial burden, c) you could be a test subject for a vaccine with unknown consequences, d) you could trust information you receive from public health officials about the vaccine, e) you would be protecting others in your community from getting infected, f) you would be well protected from getting infected with the coronavirus. Answer categories included strongly agree, somewhat agree, somewhat disagree, strongly disagree. Respondents were randomly asked either a-c (i.e. the negatively worded statements) or d-f (i.e. the positively worded statements) first, and items within each set were also randomized. The items were coded so that more pro-vaccine responses were scored 4 and more anti-vaccine responses were scored 1.

Respondents were also asked about their intentions to accept the vaccine (before they were asked about their beliefs). Specifically, the item asked: if you were able to get a vaccine for coronavirus today, what is the likelihood that you would get vaccinated? Response categories included: Very likely (4), somewhat likely (3), somewhat unlikely (2), very unlikely (1). This question was asked at both T1, and T2, with a strong association between the responses given six weeks apart (gamma $=0.79)$.

Our analyses contrast the vaccination-related beliefs with belief in misinformation, captured with an eight-item scale. Each item began with the stem: How much do you (disagree) or (agree) that: with the follow-up statements: a) Coronavirus is probably a hoax; b) Public health authorities are exaggerating the seriousness of coronavirus; c) A vaccine for the coronavirus is now available; d) The malaria drug Hydroxychloroquine is an effective treatment for coronavirus; e) A cure for coronavirus has been found; f) Information about treatments for coronavirus is being suppressed by those who want the pandemic to continue; g) Coronavirus was created in a lab; $h$ ) The coronavirus is not more dangerous than the seasonal flu. Answer categories included strongly agree (4), somewhat agree (3), not sure (2.5), somewhat disagree (2), and strongly disagree (1). We averaged responses to this set of questions and developed a misinformation scale. Elsewhere we have shown evidence for the internal coherence and validity of this scale and described how it was developed (cf. Hornik et al., 2020). The item agreeing to current vaccine availability was considered misinformation in July 2020 . The full misinformation scale was subsequently categorized as relatively low (averaging somewhat or strong disagreement across the items) or relatively high (averaging not sure, somewhat or strongly agree responses). About half of the sample (54\%) was categorized as low on belief in misinformation.

\section{Analysis}

We present crosstabular analyses examining covariation between each of the beliefs (both about vaccination consequences and misinformation) and vaccination intentions. For each 
bivariate analysis we focus attention on the proportion of respondents who say they are very likely to get vaccinated, contrasting 'very likely' responses among those who do not accept a pro-vaccine belief with those who moderately or strongly endorse a pro-vaccine belief. We also calculate Goodman and Kruskal's gamma coefficient to assess the overall association between the two variables, with full distribution (1-4 for all variables) retained, choosing that measure because the variables are measured on an ordinal scale. We also indicate what proportion of the population did not give a pro-vaccine belief. We next ask whether the association of those beliefs with intentions is different for subpopulations: for different race/ethnicity respondents; for males and females, for older and younger respondents and for those who report high levels of belief in misinformation versus low levels of belief in misinformation. To do that analysis we used full versions of the intention and belief variables and estimated ordinal logistic regressions predicting intention from each belief, the potential moderating variable and the interaction of the belief and the moderating variable. All analyses incorporate weights. Where inferential statistics are reported, they rely on the SPSS Complex Samples set of programs, which adjust standard errors for the complex weighting design.

\section{Results}

Overall, $40 \%$ of the population reported they were 'very likely' to accept a coronavirus vaccine. (24\% said somewhat likely; $35 \%$ said they were somewhat or very unlikely.) These proportions are roughly consistent with other studies examining intentions cited previously. The proportions in the current sample saying 'very likely' were sharply different for non-Latinx Black (17\%) versus non-Latinx white (46\%) or Latinx (48\%) respondents, for those over 65 (59\%) versus younger (37\%), and for those who had high (23\%) versus low (56\%) levels of misinformation. There was some difference between male (47\%) and female (35\%) respondents, but that difference was smaller than for the other comparison groups.

Table 1 presents the bivariate associations of the vaccination-specific beliefs and vaccine intentions. The first column lists the specific beliefs, differentiating anti-vaccine beliefs (the first three) from pro-vaccine beliefs (the last three). The second through fourth columns compare the percentage declaring a 'very likely' intention to get a vaccination among those who expressed an anti-vaccine belief with those who expressed a moderate or strong provaccine belief. The sample size underlying each percent estimate is presented in each cell. Again, for the sample as whole, about $40 \%$ said they were 'very likely' to be vaccinated. The final column reports the overall association of the full versions of the belief and intention variables, along with the overall $\mathrm{N}$.

Four of the six beliefs had strong associations with intention (concern about side effects, and particularly the beliefs that getting the vaccine would protect others, that it would protect oneself, and that public health authorities could be trusted). As an example, about four in ten of the respondents (337/870) thought they would suffer bad side effects from the vaccine: only $21 \%$ of this group were very likely to get the vaccine; in contrast among those who strongly disagreed with this, $78 \%$ declared they were very likely to get the vaccine (Gamma, capturing the overall strength of the relationship was .602). Two negative beliefs (that it would be a financial burden to get the vaccine, and that one might be a test subject) were often believed 
(four in ten and six in ten, respectively) but had a less definitive relation with intention (with gammas of .337 and .262).

Table 1: Association of intentions to vaccinate with vaccine-specific beliefs.

\begin{tabular}{|c|c|c|c|c|}
\hline \multirow[b]{2}{*}{$\begin{array}{l}\text { Belief: if you were to receive a potential } \\
\text { coronavirus vaccine .... }\end{array}$} & \multicolumn{3}{|c|}{$\begin{array}{l}\text { \% saying very likely to accept vaccine among } \\
\text { those who expressed anti or pro vaccine beliefs: }\end{array}$} & \multirow[t]{2}{*}{$\begin{array}{l}\text { Gamma } \\
(\mathrm{N})\end{array}$} \\
\hline & $\begin{array}{l}\text { Anti-vaccine } \\
\text { belief }\end{array}$ & $\begin{array}{l}\text { Moderate } \\
\text { pro-vaccine } \\
\text { belief }\end{array}$ & $\begin{array}{l}\text { Strongly pro- } \\
\text { vaccine belief }\end{array}$ & \\
\hline Anti-vaccine beliefs & $\begin{array}{l}\text { Somewhat or } \\
\text { strongly Agree }\end{array}$ & $\begin{array}{l}\text { somewhat } \\
\text { disagree }\end{array}$ & $\begin{array}{l}\text { strongly } \\
\text { disagree }\end{array}$ & \\
\hline $\begin{array}{l}\text { you would suffer bad side effects from } \\
\text { the vaccine }\end{array}$ & $\begin{array}{l}21 \%^{\wedge} \\
(337)\end{array}$ & $\begin{array}{l}56 \% \\
(342)\end{array}$ & $\begin{array}{l}78 \% \\
(91)\end{array}$ & $\begin{array}{l}0.602 \\
(870)\end{array}$ \\
\hline it would be a financial burden & $\begin{array}{l}25 \% \\
(333)\end{array}$ & $\begin{array}{l}42 \% \\
(289)\end{array}$ & $\begin{array}{l}59 \% \\
(256)\end{array}$ & $\begin{array}{l}0.337 \\
(878)\end{array}$ \\
\hline $\begin{array}{l}\text { you could be a test subject for a vaccine } \\
\text { with unknown consequences }\end{array}$ & $\begin{array}{l}34 \% \\
(511)\end{array}$ & $\begin{array}{l}57 \% \\
(185)\end{array}$ & $\begin{array}{l}43 \% \\
(185)\end{array}$ & $\begin{array}{l}0.262 \\
(881)\end{array}$ \\
\hline Pro-vaccine beliefs & $\begin{array}{l}\text { Somewhat or } \\
\text { strongly Disagree }\end{array}$ & $\begin{array}{l}\text { somewhat } \\
\text { agree }\end{array}$ & Strongly agree & \\
\hline $\begin{array}{l}\text { you could trust information you receive } \\
\text { from public health officials about the } \\
\text { vaccine }\end{array}$ & $\begin{array}{l}12 \% \\
(304)\end{array}$ & $\begin{array}{l}41 \% \\
(354)\end{array}$ & $\begin{array}{l}80 \% \\
(221)\end{array}$ & $\begin{array}{l}0.737 \\
(878)\end{array}$ \\
\hline $\begin{array}{l}\text { you would be protecting others in your } \\
\text { community from getting infected }\end{array}$ & $\begin{array}{l}6 \% \\
(233)\end{array}$ & $\begin{array}{l}33 \% \\
(354)\end{array}$ & $\begin{array}{l}77 \% \\
(292)\end{array}$ & $\begin{array}{l}0.755 \\
(879)\end{array}$ \\
\hline $\begin{array}{l}\text { you would be well protected from } \\
\text { getting infected with the coronavirus }\end{array}$ & $\begin{array}{l}7 \% \\
(283)\end{array}$ & $\begin{array}{l}49 \% \\
(464)\end{array}$ & $\begin{array}{l}82 \% \\
(134)\end{array}$ & $\begin{array}{l}0.769 \\
(881)\end{array}$ \\
\hline
\end{tabular}

$\wedge \%$ who said they were 'very likely' to get the COVID vaccination among those $(\mathrm{N}=337)$ agreeing or strongly agreeing with the anti-vaccine belief "you would suffer bad side effects from the vaccine".

Moderator analyses show that the four potential moderating variables did not, in fact, consistently affect the level of those associations. We estimated 24 ordinal logistic regressions for intention on each of the six beliefs, the four moderating variables, and their interactions. Only 3 of the 24 interactions were different from 0 , and there was no more than one significant interaction for any moderating variable and for any one belief. These analyses can be found in supplemental table S-1.

The final table in this section presents an analysis showing that the misinformation scale, while associated with vaccination intentions, is no longer a significant predictor once the behavioral beliefs are accounted for. For this analysis we use the full versions of each of the variables (intentions 1-4 (with 4='very likely'); beliefs coded 1-4; and misinformation coded 1-4.) In model 1 we assess the association of misinformation with intention; in model 2 each of the behavioral beliefs are included. The misinformation scale is a significant predictor in Model 1; its effects are no longer significant once the behavioral beliefs are entered in Model 2. 
Table 2: Association of misinformation and positive vaccination intentions with and without adjustments for vaccine-specific beliefs; Ordinal Logistic Regressions, weighted. $(\mathrm{N}=859)$

\begin{tabular}{|c|c|c|c|}
\hline & & Model 1 & Model 2 \\
\hline Predictors & $\begin{array}{l}\text { \% somewhat } \\
\text { or strongly } \\
\text { agreeing }\end{array}$ & $\mathrm{OR}(\mathrm{Cl})$ & $\mathrm{OR}(\mathrm{Cl})$ \\
\hline $\begin{array}{l}\text { you would suffer bad side } \\
\text { effects from the vaccine }{ }^{\wedge}\end{array}$ & $50 \%$ & & $.558(.401-.775)$ \\
\hline it would be a financial burden^ & $38 \%$ & & $.818(.664-1.008)$ \\
\hline $\begin{array}{l}\text { you could be a test subject for } \\
\text { a vaccine with unknown } \\
\text { consequences }^{\wedge}\end{array}$ & $58 \%$ & & $1.054(.853-1.302)$ \\
\hline $\begin{array}{l}\text { you could trust information you } \\
\text { receive from public health } \\
\text { officials about the vaccine }\end{array}$ & $66 \%$ & & $1.759(1.234-2.509)$ \\
\hline $\begin{array}{l}\text { you would be protecting others } \\
\text { in your community from } \\
\text { getting infected^ }\end{array}$ & $73 \%$ & & $2.409(1.691-3.433)$ \\
\hline $\begin{array}{l}\text { you would be well protected } \\
\text { from getting infected with the } \\
\text { coronavirus }^{\wedge}\end{array}$ & $66 \%$ & & $1.993(1.301-3.052)$ \\
\hline Misinformation scale ${ }^{\#}$ & & $.295(.226-.385)$ & $.889(.629-1.256)$ \\
\hline Nagelkerke pseudo r-square & & .171 & .559 \\
\hline
\end{tabular}

$\wedge$ 1=strongly disagree; 4=strongly agree; agreement for the first three variables is antivaccine, for the second three agreement is pro-vaccine.

\# 1=low misinformation 4=high misinformation

\section{Discussion}

Consistent with other studies, we find that vaccination intentions vary sharply in the population. We show that vaccine-specific beliefs are related to intentions to vaccinate, with four of the six tested beliefs showing very substantial relationships. In addition, we show that these belief-intention associations are not consistently moderated by four variables (including race/ethnicity, misinformation, age, and gender) although all four are themselves predictors of vaccination intentions. We also show that the set of vaccine-related beliefs completely account for any association of misinformation and intentions.

Can we then confidently recommend that campaign planners develop persuasive interventions designed to affect the four strongest of these beliefs: that 'the vaccine has few side effects', that 'it will protect others from the virus', that 'it will protect oneself from the virus,' and that 'public health authorities can be trusted as a source of information'? Can planners assume (for example) that if they convince skeptics that the vaccine will protect them from the virus that they will increase intentions to get vaccinated? And can we further infer that there is no particular need to directly address misinformation, if it is possible instead to directly address 
behavioral beliefs, knowing that misinformation levels are unrelated to intentions, once vaccination-specific beliefs are controlled?

These are cross-sectional associations and thus do not permit easy causal inferences. We cannot be sure about causal direction; for example, is intention to get a vaccine affected by a belief in one of these consequences or, instead, is the intention influencing agreement with the measured beliefs? We cannot be sure that these beliefs are influential for themselves, or because they are correlates of a larger set of beliefs about consequences which are the 'true' influences on vaccination intentions. And we cannot be sure that the observed associations (as large as they are) would not be reduced if further adjustments for potential covariates were made. All of these threats to inference will constrain a leap from these strong associations to a choice of campaign message themes. Also, even were these beliefs causally related to vaccination intentions and behavior, we cannot assume that particularly messages produced to influence these beliefs will be successful. Nonetheless, they deserve attention as campaign planners map a strategy.

Here are some justifications for taking these results seriously as a foundation for planning.

- They are better than the alternatives. As a practical matter, one cannot undertake ecologically valid experimental tests to choose among a range of alternative message themes; experimental tests would require development of high-quality persuasive messages operationalizing multiple candidate themes and then exposing representative audience members to such messages over time and in realistic circumstances. Each of those steps would typically be difficult and expensive to realize.

- They are better than the alternatives. A common alternative approach would be to undertake some form of qualitative research (focus groups or extended individual interviews) to assess people's openness to different messages. Insights may well come from this form of research, but such approaches are perhaps better at generating possible ideas than establishing in a systematic way which of a range of beliefs merit priority. They may support judgment about which already produced messages are appealing; they are not usually constructed to allow choices among beliefs not yet realized in messages, nor can they suggest which beliefs are associated with desired outcomes.

- In the specific case of COVID vaccination-related beliefs, we have a striking set of results. These beliefs show large associations; they unmistakably differentiate those more and less open to vaccination. The fact is: campaigners have to choose a strategy; perhaps these data provide as strong a basis for the choice of which beliefs to prioritize as is available.

But there are next steps, consistent with adopting the logic of this analysis.

- Our study focuses on six beliefs as potential targets; we recognize that they are a subset of the possible beliefs a campaign might address (the survey data used for this analysis had limited space for vaccine belief questions). It would be a high priority to extend this 
research to a wider range of potential target beliefs and compare them with those considered here.

- These data were gathered in July 2020; the vaccination environment and the COVID policy environment have changed since then and are changing (most strikingly, we now have vaccines that apparently are highly protective with minimal side effects). It may be that reluctance to vaccinate has been reduced, or the beliefs that are related to such intentions have changed. The groups that have expressed wariness may have changed. The need for ongoing research which both captures a greater range of possible beliefs, and which shows what beliefs are now related to vaccine wariness, and for which subpopulations is a priority. In addition, the COVID and vaccination environment will continue to evolve, and thus may require not a single new research project, but an ongoing process of data collection and analysis in service to campaign planning.

- This approach assists in establishing priorities for message themes: which beliefs deserve more or less attention. It does not tell creative staff how to realize messages: it requires them to develop messages recognizing that these beliefs are the target for their campaigns. For both creative staff and evaluators, changing those beliefs is a foundational criterion for success (along with eventual change in vaccination acceptance). 


\section{References}

Brennan, E., Gibson, L. A., Kybert-Momjian, A., Liu, J., \& Hornik, R. C. (2017). Promising themes for antismoking campaigns targeting youth and young adults. Tobacco regulatory science, 3(1), 29-46.

Consumer Reports. https://www.consumerreports.org/life-family/how-coronavirus-haschanged-americans-daily-lives-survey/ Accessed online 11/20/2020.

Head, K. J., Kasting, M. L., Sturm, L. A., Hartsock, J. A., \& Zimet, G. D. (2020). A National Survey Assessing SARS-CoV-2 Vaccination Intentions: Implications for Future Public Health Communication Efforts. Science Communication, 42(5), 698-723.

Hornik, R., Kikut, A., Jesch, E., Woko, C., Siegel, L., \& Kim, K. (2020). Association of COVID-19 Misinformation with Face Mask Wearing and Social Distancing in a Nationally Representative US Sample. Health Communication DOI: 10.1080/10410236.2020.1847437

Hornik, R., \& Woolf, K. D. (1999). Using cross-sectional surveys to plan message strategies. Social Marketing Quarterly, 5(2), 34-41.

Lee, S. J., Brennan, E., Gibson, L. A., Tan, A. S., Kybert-Momjian, A., Liu, J., \& Hornik, R. (2016). Predictive validity of an empirical approach for selecting promising message topics: $A$ randomized-controlled study. Journal of Communication, 66(3), 433-453.

Social Science Research Solutions (SSRS). (n.d.). Retrieved June 27, 2020, from https://ssrs.com/opinion-panel/

Thigpen, C. L., \& Funk, C. (2020). Most Americans expect a COVID-19 vaccine within a year; $72 \%$ say they would get vaccinated. Pew Research Center.

Woko, C. Siegel, L. Hornik, R. (2020 An investigation of low COVID-19 vaccination intentions among Black Americans: the role of behavioral beliefs and trust in COVID-19 information sources (Accepted for publication. Journal of Health Communication. Preprint available at DOI 10.31234/osf.io/r3fma) 
Supplemental Tables: Ordinal Regression, predicting intention from each belief, moderator and their interaction. Significance ( $p$-value) of each term reported.

\begin{tabular}{|l|l|l|l|}
\hline Race/Ethnicity (White, Black, Latinx) & $\begin{array}{l}\text { Main effect } \\
\text { of Belief }\end{array}$ & $\begin{array}{l}\text { Main effect } \\
\text { of } \\
\text { moderator }\end{array}$ & $\begin{array}{l}\text { Interaction of } \\
\text { belief and } \\
\text { moderator }\end{array}$ \\
\hline $\begin{array}{l}\text { you would suffer bad side effects from the } \\
\text { vaccine }\end{array}$ & $<.001$ & .117 & .259 \\
\hline it would be a financial burden & $<.001$ & .053 & .286 \\
\hline $\begin{array}{l}\text { you could be a test subject for a vaccine with } \\
\text { unknown consequences }\end{array}$ & .016 & .171 & .296 \\
\hline $\begin{array}{l}\text { you could trust information you receive from } \\
\text { public health officials about the vaccine }\end{array}$ & $<.001$ & .766 & .561 \\
\hline $\begin{array}{l}\text { you would be protecting others in your } \\
\text { community from getting infected }\end{array}$ & $<.001$ & .308 & .188 \\
\hline $\begin{array}{l}\text { you would be well protected from getting } \\
\text { infected with the coronavirus }\end{array}$ & $<.001$ & .223 & .157 \\
\hline
\end{tabular}

\begin{tabular}{|l|l|l|l|}
\hline Age $(<65,65+)$ & $\begin{array}{l}\text { Main effect } \\
\text { of Belief }\end{array}$ & $\begin{array}{l}\text { Main effect } \\
\text { of } \\
\text { moderator }\end{array}$ & $\begin{array}{l}\text { Interaction of } \\
\text { belief and } \\
\text { moderator }\end{array}$ \\
\hline $\begin{array}{l}\text { you would suffer bad side effects from the } \\
\text { vaccine }\end{array}$ & $<.001$ & .344 & .187 \\
\hline $\begin{array}{l}\text { it would be a financial burden } \\
\text { you could be a test subject for a vaccine with } \\
\text { unknown consequences }\end{array}$ & .016 & .091 & .336 \\
\hline $\begin{array}{l}\text { you could trust information you receive from } \\
\text { public health officials about the vaccine }\end{array}$ & $<.001$ & .001 & .233 \\
\hline $\begin{array}{l}\text { you would be protecting others in your } \\
\text { community from getting infected }\end{array}$ & $<.001$ & .123 & .009 \\
\hline $\begin{array}{l}\text { you would be well protected from getting } \\
\text { infected with the coronavirus }\end{array}$ & $<.001$ & .152 & .099 \\
\hline
\end{tabular}




\begin{tabular}{|l|l|l|l|}
\hline Gender (Female/Male) & $\begin{array}{l}\text { Main effect } \\
\text { of Belief }\end{array}$ & $\begin{array}{l}\text { Main effect } \\
\text { of } \\
\text { moderator }\end{array}$ & $\begin{array}{l}\text { Interaction of } \\
\text { belief and } \\
\text { moderator }\end{array}$ \\
\hline $\begin{array}{l}\text { you would suffer bad side effects from the } \\
\text { vaccine }\end{array}$ & $<.001$ & .695 & .746 \\
\hline it would be a financial burden & $<.001$ & .073 & .199 \\
\hline $\begin{array}{l}\text { you could be a test subject for a vaccine with } \\
\text { unknown consequences }\end{array}$ & $<.001$ & .010 & .032 \\
\hline $\begin{array}{l}\text { you could trust information you receive from } \\
\text { public health officials about the vaccine }\end{array}$ & $<.001$ & .690 & .896 \\
\hline $\begin{array}{l}\text { you would be protecting others in your } \\
\text { community from getting infected }\end{array}$ & $<.001$ & .749 & .665 \\
\hline $\begin{array}{l}\text { you would be well protected from getting } \\
\text { infected with the coronavirus }\end{array}$ & $<.001$ & .944 & .520 \\
\hline
\end{tabular}

\begin{tabular}{|l|l|l|l|}
\hline Misinformation (lower/higher) & $\begin{array}{l}\text { Main effect } \\
\text { of Belief }\end{array}$ & $\begin{array}{l}\text { Main effect } \\
\text { of } \\
\text { moderator }\end{array}$ & $\begin{array}{l}\text { Interaction of } \\
\text { belief and } \\
\text { moderator }\end{array}$ \\
\hline $\begin{array}{l}\text { you would suffer bad side effects from the } \\
\text { vaccine }\end{array}$ & $<.001$ & .041 & .569 \\
\hline it would be a financial burden & $<.001$ & $<.001$ & .017 \\
\hline $\begin{array}{l}\text { you could be a test subject for a vaccine with } \\
\text { unknown consequences }\end{array}$ & $<.001$ & .009 & .923 \\
\hline $\begin{array}{l}\text { you could trust information you receive from } \\
\text { public health officials about the vaccine }\end{array}$ & $<.001$ & .079 & .269 \\
\hline $\begin{array}{l}\text { you would be protecting others in your } \\
\text { community from getting infected }\end{array}$ & $<.001$ & .124 & .457 \\
\hline $\begin{array}{l}\text { you would be well protected from getting } \\
\text { infected with the coronavirus }\end{array}$ & $<.001$ & .626 & .556 \\
\hline
\end{tabular}

